\title{
Identification and Monitoring of Amomi Fructus and its Adulterants Based on DNA Barcoding Analysis and Designed DNA Markers
}

\author{
Eui Jeong Doh ${ }^{1,2}$, Jung-Hoon $\mathrm{Kim}^{3}$ and Guemsan Lee ${ }^{1,2, *(1)}$ \\ 1 Department of Herbology, College of Korean Medicine, Wonkwang University, Iksan 54538, Korea; \\ bluemoonlion@wku.ac.kr \\ 2 Research Center of Traditional Korean Medicine, Wonkwang University, Iksan 54538, Korea \\ 3 Division of Pharmacology, School of Korean Medicine, Pusan National University, Yangsan 50612, Korea; \\ kmsct@pusan.ac.kr \\ * Correspondence: rasfin@wku.ac.kr; Tel.: +82-63-850-6985
}

Received: 18 October 2019; Accepted: 13 November 2019; Published: 19 November 2019

\begin{abstract}
Amomi Fructus is one of the traditional medicines derived from the ripe fruits of the Zingiberaceae family of plants, which include Amomum villosum, A. villosum var. xanthioides, and A. longiligulare. Owing to their highly similar morphological traits, several kinds of adulterants of Amomi Fructus have been reported. Therefore, accurate and reliable methods of identification are necessary in order to ensure drug safety and quality. We performed DNA barcoding using five regions (ITS, matK, rbcL, rpoB, and trnL-F intergenic spacer) of 23 Amomi Fructus samples and 22 adulterants. We designed specific DNA markers for Amomi Fructus based on the single nucleotide polymorphisms (SNPs) in the ITS. Amomi Fructus was well separated from the adulterants and was classified with the species of origin based on the detected SNPs from the DNA barcoding results. The AVF1/ISR DNA marker for A. villosum produced a 270 bases amplified product, while the ALF1/ISF DNA marker produced a 350 bases product specific for A. longiligulare. Using these DNA markers, the monitoring of commercially distributed Amomi Fructus was performed, and the monitoring results were confirmed by ITS analysis. This method identified samples that were from incorrect origins, and a new species of adulterant was also identified. These results confirmed the accuracy and efficiency of the designed DNA markers; this method may be used as an efficient tool for the identification and verification of Amomi Fructus.
\end{abstract}

Keywords: Amomi Fructus; Amomum villosum; Amomum villosum var. xanthioide; A. longiligulare; adulterants; DNA barcode; DNA marker; multiplex PCR

\section{Introduction}

Amomi Fructus, which is derived from species of cardamom plants, is an important traditional medicine used for curing digestive diseases, rheumatism, malaria, toothache, eliminating dampness, and promoting appetite [1,2]. It is also used as an ingredient in the production of cosmetic and food products. The ripe fruits from Amomum villosum Lour., A. villosum var. xanthioides Wall. ex Baker, T.L.Wu and S.J.Chen, and A. longiligulare T.L.Wu are known as the origin of Amomi Fructus [1]. However, there are differences in the definition of original species of Amomi Fructus among pharmacopeias of Korea, China, and Taiwan [3]. Amomi Fructus originates from the fruits of A. villosum and A. villosum var. xanthioides in Korean pharmacopeia [4], while the fruits of $A$. longiligulare in addition to those two species are listed as Amomi Fructus in both Chinese and Taiwan pharmacopeias $[5,6]$. Previous studies have reported that the content of borenol acetate as an active ingredient was significantly higher in the 
fruit of A. villosum than in A. villosum var. xanthioides and A. longiligulare, which explains the better therapeutic effect of $A$. villosum $[7,8]$.

However, Amomi Fructus is frequently adulterated with the products of other Amomum species and even species from the genus Alpinia in the commercial herbal market [9-11]; over fifteen species in the genera Amomum and Alpinia have been reported as adulterants owing to their similar morphological and anatomical characteristics [11]. Moreover, similarities in morphological appearance also makes macroscopic distinction of the three genuine Amomum species much more difficult as they show few morphological differences [12].

Hence, accurate and reliable methods for the identification of Amomi Fructus are necessary to ensure quality and safety in medication, which can be guaranteed by using genuine products and avoiding adulterants. DNA barcoding is known as an efficient and accurate method of identifying species based on nucleotide diversity in short DNA segments. In several previous studies, samples of Amomi Fructus were genetically identified based on various DNA analytic techniques such as inter simple sequence repeats(ISSR)-PCR [13], random amplification of polymorphic DNA (RAPD) [14] and DNA barcoding, such as internal transcribed spacer (ITS) 1, ITS 2 and ITS including 5.8s rDNA and some plastid loci $[15,16]$. From previous studies, the DNA barcoding method is considered as a useful and reliable molecular tool for the identification of Amomi Fructus and its adulterants. The chloroplast (cp) genome has been established as the proper region for the DNA barcode for identifying the species in plants, especially between closely related species [17].

Therefore, in the present study, we used DNA barcoding analysis using five regions (ITS, matK, $r b c L, r p o B$, and $t r n L-F$ intergenic spacer) for genetic identification and evaluation of Amomi Fructus and its adulterants. Furthermore, we attempted to provide the DNA marker for the correct origins of Amomi Fructus based on the determined nucleotide sequences using the results of DNA barcoding analysis in this study.

\section{Results}

\subsection{DNA Barcode Analysis}

\subsubsection{Internal Transcribed Spacer (ITS) Regions of Nuclear Ribosomal Cistron}

To identify Amomi Fructus from several possible adulterants, the nucleotide sequences of the ITS region were analyzed. Approximately $645-665$ bases of amplified product sequence was identified based on the samples listed in Table 1. The results of sequence characteristics were represented in Table 2. Among the original species of Amomi Fructus origin, 19 different nucleotides were observed from A. villosum var. xanthioides, A. villosum, and A. longiligulare (Figure 1). Although some intraspecific variations were detected in $A$. villosum species (AV01-AV18), these variations did not compromise the ability of distinguishing the original species of Amomi Fructus from the possible adulterants. The sequence identity matrix was 1 (maximum) to 0.974 (minimum) among the three species of Amomi Fructus (Table S1). The phylogenetic analysis showed that the samples of A. villosum formed a closer relationship with those of $A$. villosum var. xanthioides than with those of $A$. longiligulare. The sequence identity matrix ranged from $0.936-0.904$ in adulterants of genus Amomum, while it ranged from 0.894 to 0.844 in adulterants of the genus Alpinia. The results of the phylogenetic analysis inferred through ITS nucleotide sequences showed that samples of genuine Amomi species formed a closer relationship and their groups were apparently distinguished from the other Amomum and Alpinia species which were recognized as adulterants (Figure 2). 
Table 1. The collected Amomi Fructus and Zingiberaceae plants samples used in this study.

\begin{tabular}{|c|c|c|c|}
\hline No. & Sample Code & Scientific Name & Medicinal Name \\
\hline 1 & AV01 & \multirow{18}{*}{$\begin{array}{c}\text { Amomum villosum Lour. } \\
\text { (=Wurfbainia villosa (Lour.) Skornick. A.D.Poulsen) }\end{array}$} & \multirow{18}{*}{ Amomi Fructus ${ }^{* * *}$} \\
\hline 2 & AV02 & & \\
\hline 3 & AV03 & & \\
\hline 4 & AV04 & & \\
\hline 5 & AV05 & & \\
\hline 6 & AV06 & & \\
\hline 7 & AV07 & & \\
\hline 8 & AV08 & & \\
\hline 9 & AV09 & & \\
\hline 10 & AV10 & & \\
\hline 11 & AV11 & & \\
\hline 12 & AV12 & & \\
\hline 13 & AV13 & & \\
\hline 14 & AV14 & & \\
\hline 15 & AV15 & & \\
\hline 16 & AV16 & & \\
\hline 17 & AV17 & & \\
\hline 18 & AV18 & & \\
\hline 19 & AL01 & \multirow{5}{*}{$\begin{array}{c}\text { Amomum longiligulare T.L.Wu } \\
\text { (=Wurfbainia longiligularis (T.L.Wu) Skornick. A.D. } \\
\text { Poulsen) }\end{array}$} & \multirow{5}{*}{ Amomi Fructus $* *$} \\
\hline 20 & AL02 & & \\
\hline 21 & AL03 & & \\
\hline 22 & AL04 & & \\
\hline 23 & AL05 & & \\
\hline 24 & AK01 & \multirow{4}{*}{$\begin{array}{c}\text { Amomum verum Blackw. } \\
\text { (=Amomum krervanh Pierre ex Gagnep.) }\end{array}$} & \multirow{8}{*}{$\begin{array}{l}\text { Amomi Fructus } \\
\text { Rotundus }\end{array}$} \\
\hline 25 & $\mathrm{AK} 02$ & & \\
\hline 26 & $\mathrm{AK} 03$ & & \\
\hline 27 & AK04 & & \\
\hline 28 & AC01 & \multirow{4}{*}{ Amomum compactum Sol. ex Maton } & \\
\hline 29 & $\mathrm{ACO} 2$ & & \\
\hline 30 & $\mathrm{ACO} 3$ & & \\
\hline 31 & $\mathrm{AC} 04$ & & \\
\hline 32 & ATK01 & \multirow{4}{*}{$\begin{array}{l}\text { Amomum tsao-ko Crevost Lemarié } \\
\qquad(=\text { Amomum tsaoko })\end{array}$} & \multirow{4}{*}{ Amomi Tsao-ko Fructus } \\
\hline 33 & ATK02 & & \\
\hline 34 & ATK03 & & \\
\hline 35 & ATK04 & & \\
\hline 36 & AH01 & \multirow{4}{*}{$\begin{array}{l}\text { Alpinia hainanensis K.Schum. } \\
\text { (=Alpinia katsumadae Hayata) }\end{array}$} & \multirow{4}{*}{$\begin{array}{l}\text { Alpiniae Katsumadai } \\
\text { Semen }\end{array}$} \\
\hline 37 & $\mathrm{AH} 02$ & & \\
\hline 38 & $\mathrm{AH} 03$ & & \\
\hline 39 & $\mathrm{AH} 04$ & & \\
\hline 40 & $\mathrm{AO} 01$ & \multirow{4}{*}{ Alpinia oxyphylla Miq. } & \multirow{4}{*}{$\begin{array}{l}\text { Alpiniae Oxyphyllae } \\
\text { Fructus }\end{array}$} \\
\hline 41 & $\mathrm{AO} 02$ & & \\
\hline 42 & $\mathrm{AO} 03$ & & \\
\hline 43 & $\mathrm{AO} 04$ & & \\
\hline 44 & AOR01 & \multirow{4}{*}{ Alpinia officinarum Hanc } & \multirow{4}{*}{$\begin{array}{l}\text { Alpiniae Officinari } \\
\text { Rhizoma }\end{array}$} \\
\hline 45 & AOR02 & & \\
\hline 46 & AOR03 & & \\
\hline 47 & AOR04 & & \\
\hline 48 & ACC01 & \multirow{2}{*}{ Alpinia conchigera Griff. } & \multirow{2}{*}{ jie bian shan jiang ${ }^{* * *}$} \\
\hline 49 & ACC02 & & \\
\hline 50 & AZ01 & \multirow{2}{*}{ Alpinia zerumbet (Pers.) B.L.Burtt R.M.Sm. } & \multirow{2}{*}{ yan shan jiang ${ }^{* * *}$} \\
\hline 51 & AZ02 & & \\
\hline 52 & AM01 & Alpinia malaccensis(N.L.Burman) Roscoe & mao ban shan jiang ${ }^{* * *}$ \\
\hline 53 & AG01 & Alpinia galanga (L.) Willd. & Galangae Fructus \\
\hline 54 & EC01 & Elettaria cardamomum (L.) Maton & \\
\hline 55 & EC02 & (=Amomum cardamomum L., Alpinia cardamomum (L.) Roxb.) & Cardamomi Fructus \\
\hline
\end{tabular}

*: The Korean Pharmacopoeia, 11th edition; **: Pharmacopoeia of the Peoples Republic of China, Taiwan Herbal Pharmacopeia; ${ }^{* * *}$ : Flora of China [18]. 
Table 2. Amplicon size of plastid loci and nuclear barcode region in Amomi Fructus and adulterant species and the sequence characteristic, single and in different multi-region combination.

\begin{tabular}{|c|c|c|c|c|c|c|}
\hline Barcode Target & $\begin{array}{c}\text { Amplicon } \\
\text { Size } \\
\text { ( Bases) }\end{array}$ & $\begin{array}{l}\text { Aligned } \\
\text { Length } \\
\text { (Bases) }\end{array}$ & $\begin{array}{c}\text { Conserved } \\
\text { Sites }\end{array}$ & $\begin{array}{c}\text { Variable } \\
\text { Sites }\end{array}$ & $\begin{array}{c}\text { Parsimony } \\
\text { Informative } \\
\text { Sites }\end{array}$ & $\begin{array}{l}\text { Singleton } \\
\text { Sites }\end{array}$ \\
\hline ITS & $645-665$ & 670 & 516 & 154 & 132 & 22 \\
\hline matk & 933 & 933 & 894 & 39 & 27 & 12 \\
\hline$r b c L$ & 743 & 743 & 657 & 86 & 12 & 74 \\
\hline$r p o B$ & 516 & 516 & 500 & 16 & 10 & 6 \\
\hline trnL-F intergenic sapcer & $395-415$ & 422 & 377 & 43 & 13 & 30 \\
\hline matk $+r b c L$ & & 1676 & 1551 & 125 & 39 & 86 \\
\hline$r p o B+\operatorname{trn} L-F$ intergenic spacer & & 938 & 877 & 59 & 23 & 36 \\
\hline mark $+r b c L+r p o B$ & & 2192 & 2051 & 141 & 49 & 92 \\
\hline mark $+r b c L+t r n L-F$ intergenic spacer & & 2098 & 1928 & 168 & 52 & 116 \\
\hline Four plastid targets & & 2614 & 2428 & 184 & 62 & 122 \\
\hline
\end{tabular}

ITS matK rbcL rpoB trnL-F intergenic spacer

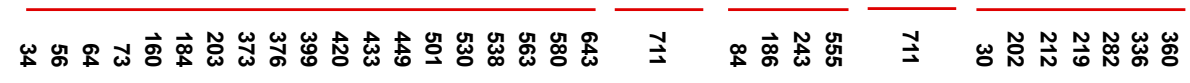

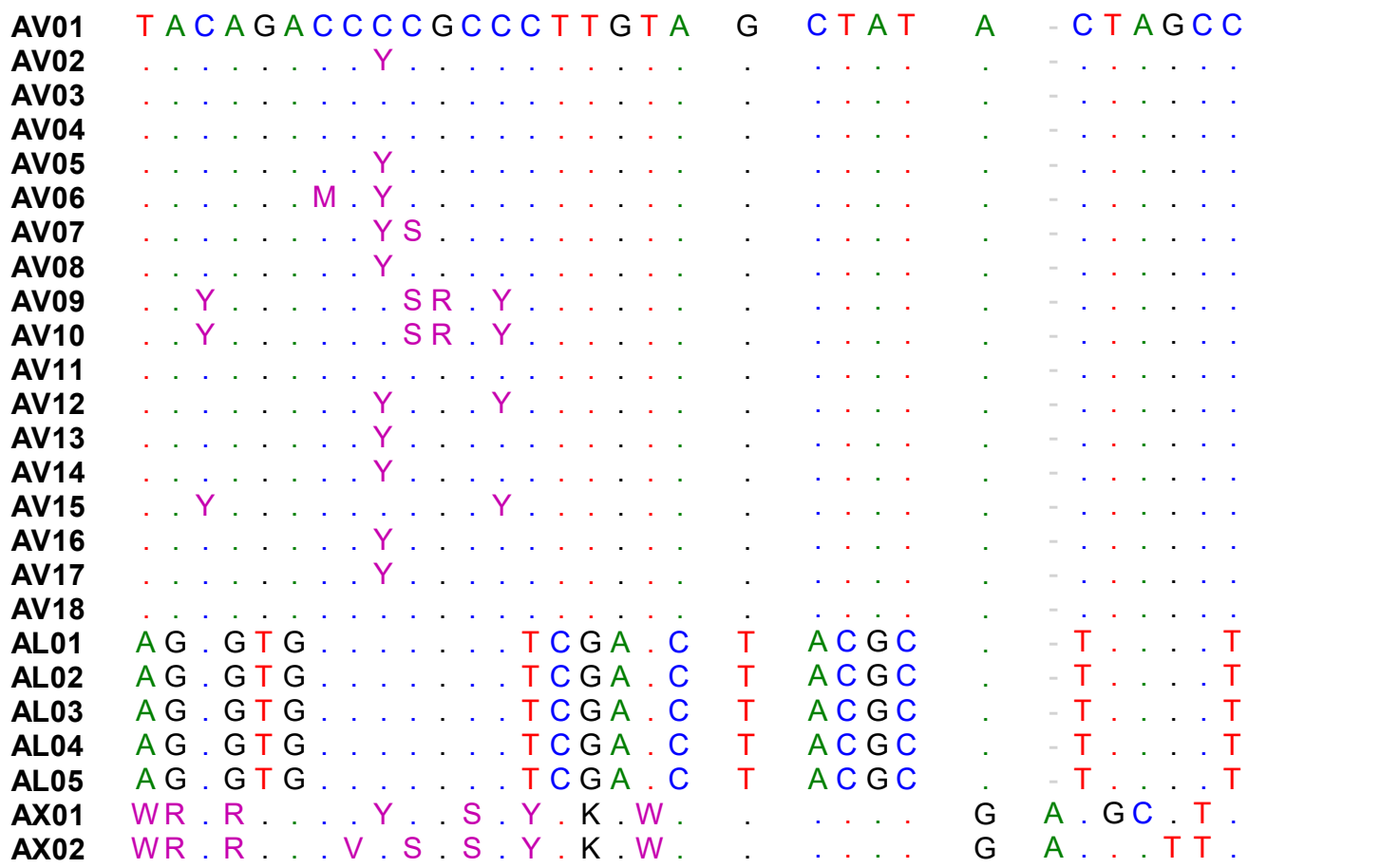

Figure 1. Multiple alignments of the 32 single nucleotide polymorphisms (SNPs) from five regions (ITS, mat $K, r b c L, r p o B$, trnL-F intergenic spacer) in Amomi Fructus. Numbers above the bases indicate the position of single-nucleotide polymorphisms in each region. The dots indicate the consensus nucleotide; Sample code shown in Table 1. Heterozygous sites were defined according to IUPAC. AX01 (A. villosum var. xanthioides): KJ151892 and MH161417; AX02 (A. villosum var. xanthioides): KJ151893 and MN067432. 


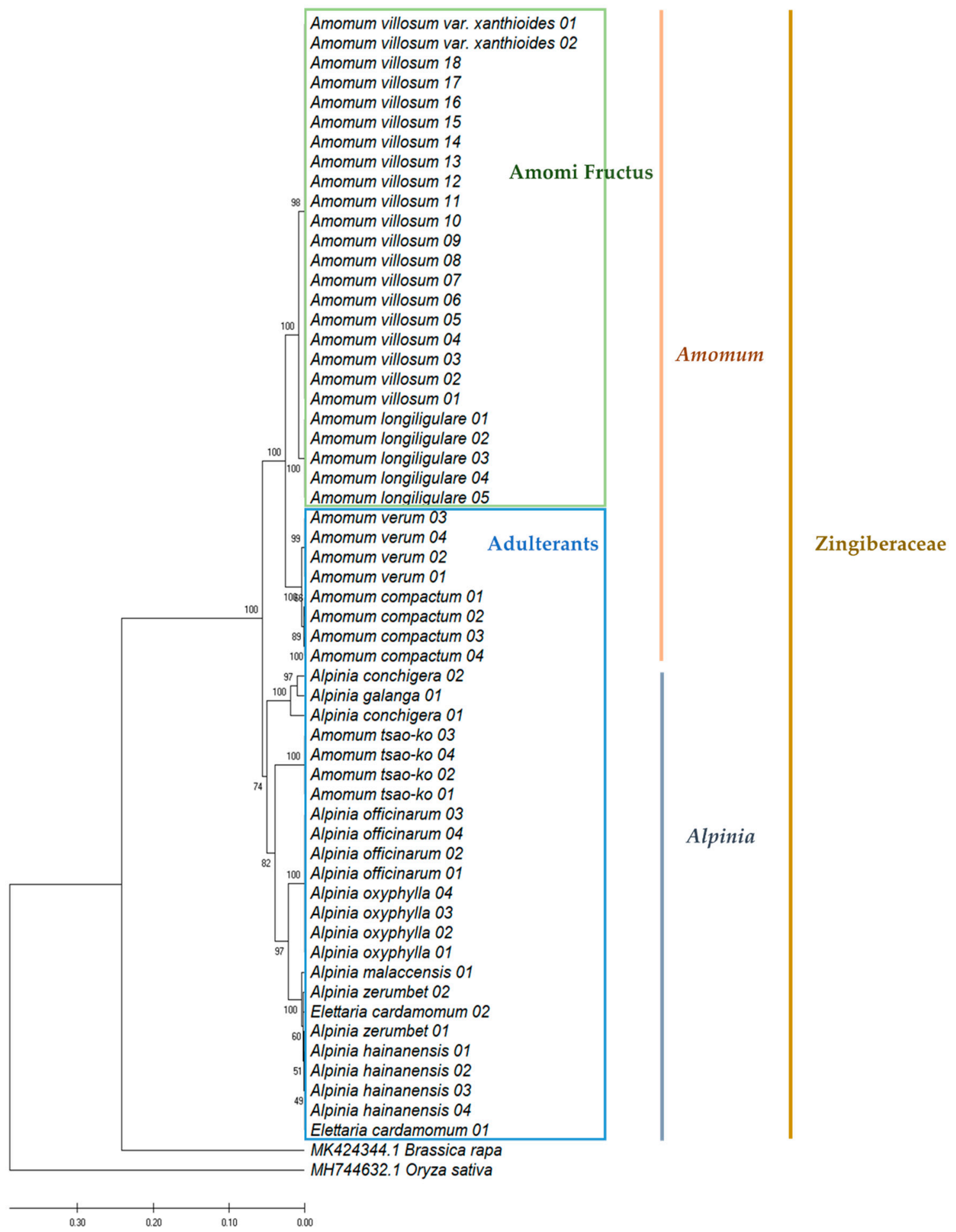

Figure 2. Phylogenetic analysis of Amomi Fructus and its adulterants based on the nucleotide sequences of internal transcribed spacer (ITS), including 5.8S rDNA region using the UPGMA method. The percentage of replicate trees in which the associated taxa clustered together in the bootstrap test (500 replicates) are shown next to the branches. The evolutionary distances were computed using the Maximum Composite Likelihood method and are in the units of the number of base substitutions per site. As outgroups, ITS nucleotide sequences of Brassica rapa (MK424344.1) and Oryza sativa (MH744632.1) were used. 


\subsubsection{Chloroplast Genome Based DNA Barcode Sequence Analysis}

Four chloroplast genome areas were analyzed to determine the proper DNA barcode for Amomi Fructus and the adulterants. Sequence characteristics of the four plastid loci and one nuclear region are given in Table 2. The amplified product size varied from 395 bases ( $t r n L-F$ intergenic spacer) to 933 bases in $m a t K$. The $r b c L$ and $t r n L-F$ intergenic spacer regions have higher variable sites among four plastid loci (except ITS region). The sequences of $m a t K$ and $r p o B$ were the most conserved among the five regions analyzed when the aligned length and number of conserved sited were taken into consideration. Even though the variable site of four plastid loci were much lower than ITS region and highly conserved, it could separate the species of Amomi Fructus from adulterants.

For more detail about the four plastid loci, the 933 bases partial nucleotide sequences of mat $K$ were determined using a 390F/1326R primer set. Unlike the ITS region, all of the samples showed the same nucleotide length, as 933 bases, that is, not only the genus Amomum, but also Alpinia. There was no intraspecific variation among the genuine species of Amomi Fructus. Further, the sequence identity matrix between Amomi Fructus and the adulterants was considerably closer as compared to the results with ITS; the minimum identity matrix result was 0.981 between Amomi Fructus and the adulterants (Table S2). As shown in Figure 1, no difference of nucleotide sequence was detected between A. villosum and $A$. villosum var. xanthioides, while only a one base difference was detected in A. longiligulare (Figure 1). Nevertheless, the phylogenetic tree analyzed by mat $K$ indicated that the original species of Amomi Fructus were well separated from the adulterants (Figure S1A).

For the $r b c L$ gene sequence, we identified a 743 bases partial nucleotide sequence in all the samples listed in Table 1 using the rbcL a-f/724R primer set. Four SNPs were observed among A. villosum, A. villosum var. xanthioides and A. longiligulare (Figure 1). There was no difference of nucleotide sequence between $A$. villosum and A. villosum var. xanthioides. The difference in the nucleotide sequence was lower than the ITS results; however, the three species of Amomi Fructus origin could still be distinguished. Although the minimum sequence identity matrix of $r b c L$ among samples in Table 1 was near 0.986 (except in the ATK samples, where the minimum sequence identity matrix was 0.896), Amomi Fructus was well separated from the adulterants according to the results of the phylogenetic relationship analysis based on the $r b c L$ nucleotide sequences (Table S2, Figure S1B).

In total, 516 bases partial nucleotide sequences were determined for the rpoB gene from the samples in Table 1. There was no difference in the nucleotide sequence between A. villosum and A. longiligulare, while only a one base difference was observed in A. villosum var. xanthioides (Figure 1). Only 16 SNPs were observed among the Amomi Fructus and several adulterants at rpoB gene (data not shown). The minimum sequence identity matrix among the samples in Table 1 was very close to 0.988 . Thus, the Amomi Fructus samples were distinguished from the adulterant samples, except for AK and AC samples (Table S2, Figure S1C).

In the case of the trnL-F intergenic spacer, 395-415 bases amplified products were determined from the samples listed in Table 1. The species of origin of Amomi Fructus were determined to be the 407-408 bases nucleotide sequences. Two base differences were observed between $A$. villosum and $A$. longiligulare. In the case of $A$. villosum var. xanthioides, intraspecific variations were observed between two previously deposited nucleotide sequences in NCBI Genbank (AX01-02). Seven bases differences, including intraspecific variations, were observed in A. villosum var. xanthioides (Figure 1). However, the amplified product size was different depending on the species and the sequence identity matrix between Amomi Fructus and the adulterants ranged from 0.975 to 0.882 (Table S2). As with the above three barcode regions, the phylogenetic tree inferred from the trnL-F intergenic spacer also showed distinguishable groups of Amomi Fructus samples from several adulterants (Figure S1D).

\subsection{DNA Marker for Amomi Fructus Based on Discrepancy in the ITS Sequences}

From the results of five DNA barcode nucleotide sequences as determined above, we confirmed that those five DNA barcode regions were suitable to differentiate genuine Amomi Fructus samples from their adulterants. However, while DNA barcoding was an efficient method to identify the origin 
of each medicinal herb, sequencing five barcode regions would be a time-consuming process for monitoring medicinal herbs distributed in the commercial market. Therefore, we attempted to develop a DNA marker for the clear and quick distinction of Amomi Fructus from adulterants based on the determined nucleotide sequences in this study. In order to design the DNA marker, ITS sequences were chosen due to their high level of interspecific variations compared to the cpDNA barcodes. As shown in Figure 3, AVF1/ISR primer sets were developed as a DNA marker for A. villosum, which produced a 270 bases amplified product for A. villosum (Figure 3). ALF1/ISF primer sets, which produced a 350 bases amplified product, were developed as an $A$. longiligulare-specific DNA marker (Figure 3). In order to confirm the PCR reaction and rule out PCR error, an ISF/ISR primer set was designed as an internal standard marker. Also, we tried to multiplex the PCR process by designing three primer sets to improve the efficiency, and to save time and costs. One PCR reaction with AVF1/ISR/ISF/ALF1 marker produced 270 bases and 100 bases PCR products in A. villosum species, while 350 bases and 100 bases PCR products were produced by A. longiligulare species (Figure 3 ). All the other samples except Amomi Fructus produced 100 bases PCR products as the internal standard.

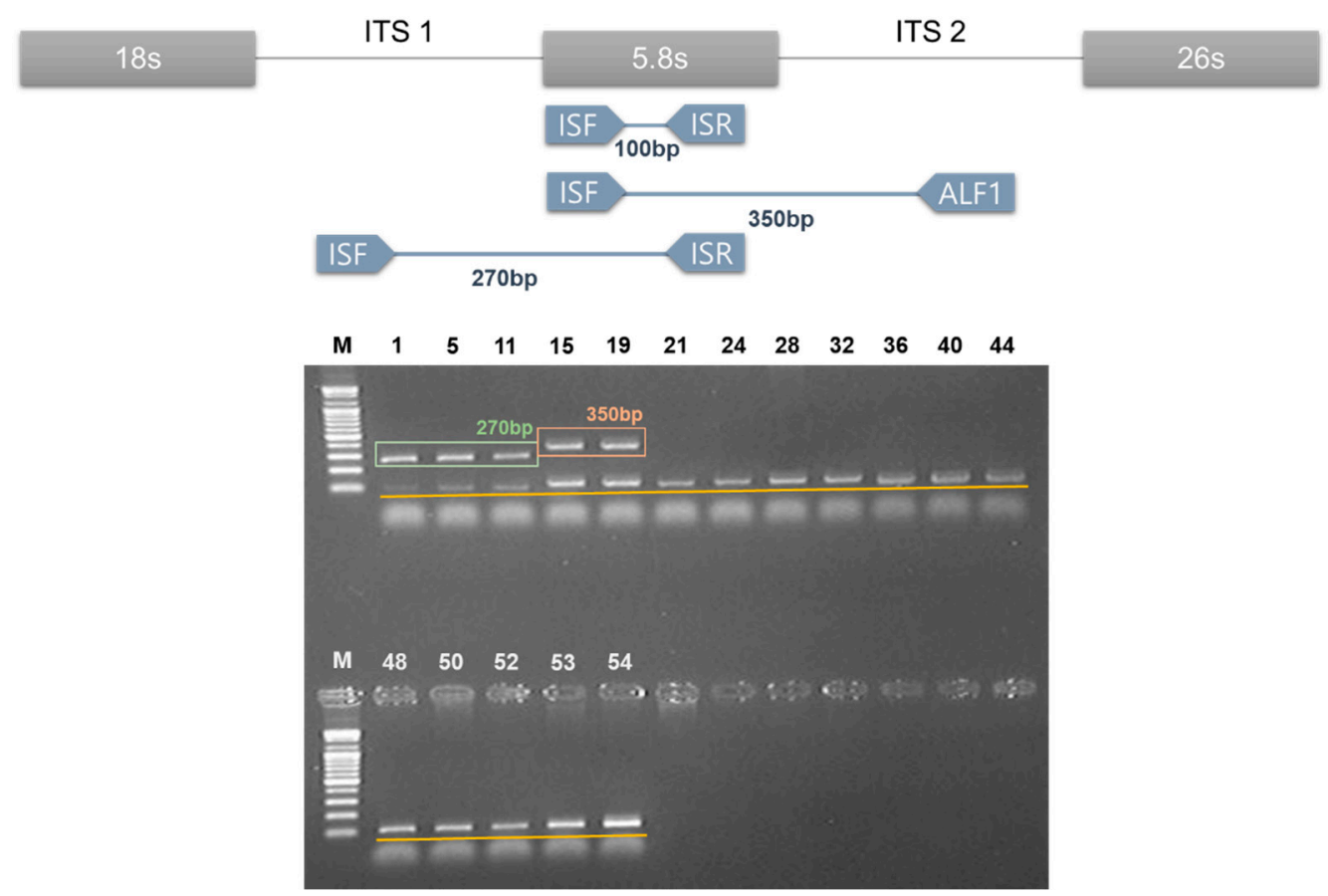

Figure 3. Multiplex PCR products of the primer set AVF1/ISR/ISF/ALF1 from randomly chosen samples in Table 1 for distinguishing Amomi Fructus from its adulterants. Lane numbers above: The sample number listed in Table 1. M: 100 bases ladder size marker.

\subsection{Monitoring Amomi Fructus Vouchers in Commercial Markets Using DNA Markers}

For the verification of the developed DNA markers, we collected and monitored 40 commercial samples sold as Amomi Fructus from various regions in the eastern and southern Asian countries (Table 3). We applied newly-developed DNA markers to identify commercial Amomi Fructus samples and thereafter confirmed their taxonomic affiliation using ITS nucleotide analysis. As shown in Figure 4, identified species of some commercial Amomi Fructus samples were not consistent with their originated species: (1) Some of the commercial A. villosum samples did not amplify with the AVF1/ISR primer set, but rather amplified with the ALF1/ISF, a specific DNA marker for A. longiligulare; (2) some of the commercial A. longiligulare samples were not amplified with the specific DNA marker set. All samples were amplified with ISF/ISR (internal standard marker), which indicates that there were no errors in the PCR reaction. 
We finally confirmed the taxonomic affiliation of commercial Amomi Fructus samples using ITS nucleotide sequence analysis (Table 3). Most of the commercial A. villosum samples were genetically re-identified as they were named. However, some samples named as A. villosum (No. 5 and No. 9) were re-identified as $A$. longiligulare and vice versa (No. 13 and 27). Sample No. 9 was mixed with A. longiligulare. Two samples (No. 12 and 26) that were named as A. longiligulare did not amplify with AVF1/ISR/ISF/ALF1 DNA marker and were re-identified as A. ghaticum K.G.Bhat, which was not previously reported as an adulterant of Amomi Fructus by using ITS nucleotide analysis combined with NCBI Blast result. All samples named as A. villosum var. xanthioides were re-identified as A. villosum (No. 17-20, 31) or A. longiligulare (No. 32). These results demonstrate that genetic identifications of commercial Amomi Fructus samples using developed DNA markers were consistent with those using the ITS nucleotide analysis.
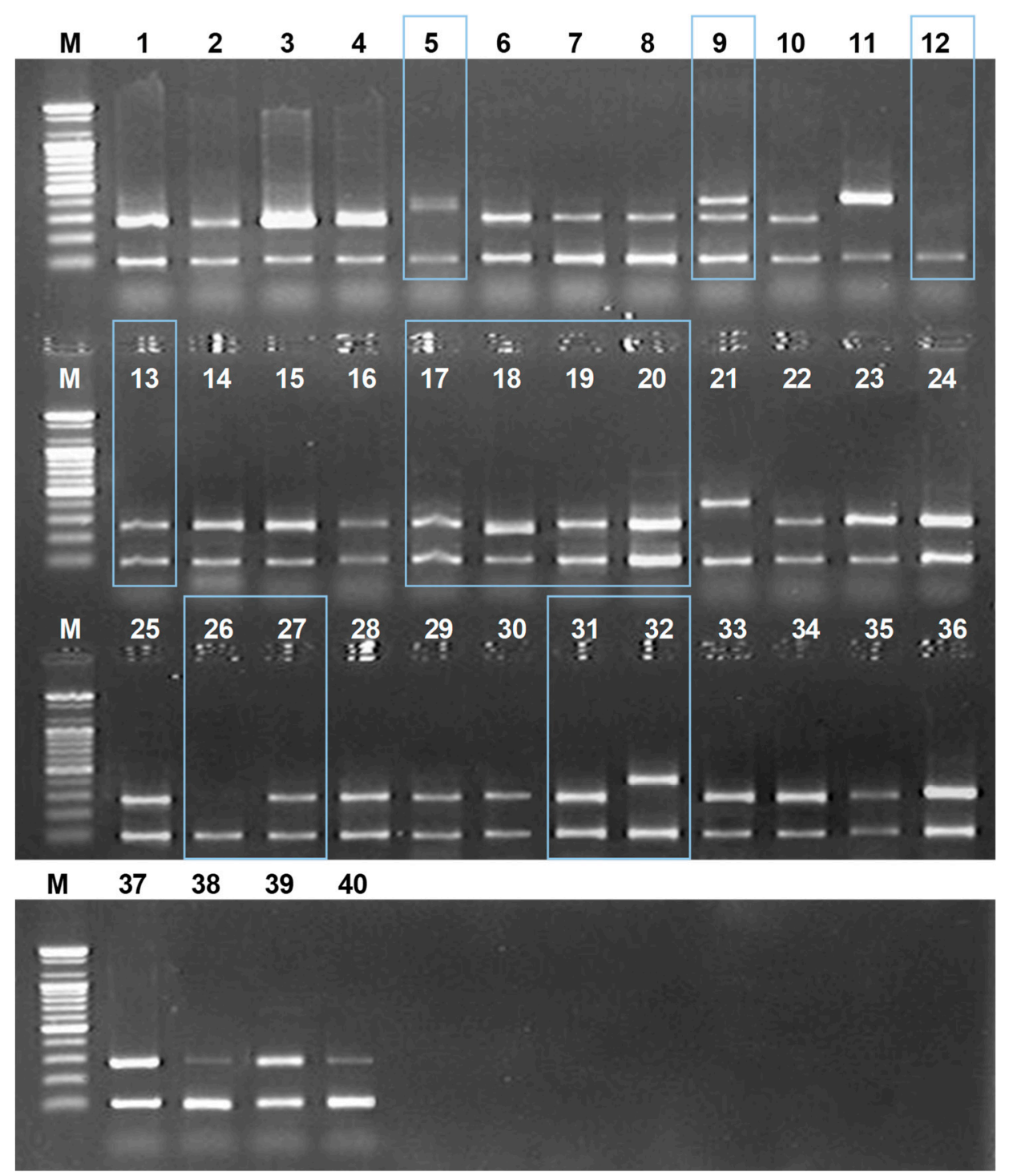

Figure 4. The monitoring results of commercial Amomi Fructus by using multiplex PCR with the designed AVF1/ISR/ISF/ALF1 primer set in this study. Lane numbers above: The sample number as listed in Table 2. M: 100 bases ladder; Box shows different amplified results than expected. 
Table 3. The re-identification results of collected monitoring samples based on ITS nucleotide sequence analysis.

\begin{tabular}{|c|c|c|c|c|c|}
\hline No & Collected Species Name & $\begin{array}{l}\text { Genetically Re-Identified } \\
\text { Species }\end{array}$ & No & Collected Species Name & $\begin{array}{c}\text { Genetically } \\
\text { Re-Identified Species }\end{array}$ \\
\hline 1 & A. villosum & A. villosum & 21 & A. longiligulare & A. longiligulare \\
\hline 2 & A. villosum & A. villosum & 22 & A. villosum & A. villosum \\
\hline 3 & A. villosum & A. villosum & 23 & A. villosum & A. villosum \\
\hline 4 & A. villosum & A. villosum & 24 & A. villosum & A. villosum \\
\hline 5 & A. villosum & A. longiligulare & 25 & A. villosum & A. villosum \\
\hline 6 & A. villosum & A. villosum & 26 & A. longiligulare & Amomum ghaticum \\
\hline 7 & A. villosum & A. villosum & 27 & A. longiligulare & A. villosum \\
\hline 8 & A. villosum & A. villosum & 28 & A. villosum & A. villosum \\
\hline 9 & A. villosum & A. villosum/A. longiligulare & 29 & A. villosum & A. villosum \\
\hline 10 & A. villosum & A. villosum & 30 & A. villosum & A. villosum \\
\hline 11 & A. longiligulare & A. longiligulare & 31 & A. villosum var. xanthioides & A. villosum \\
\hline 12 & A. longiligulare & Amomum ghaticum & 32 & A. villosum var. xanthioides & A. longiligulare \\
\hline 13 & A. longiligulare & A. villosum & 33 & A. villosum & A. villosum \\
\hline 14 & A. villosum & A. villosum & 34 & A. villosum & A. villosum \\
\hline 15 & A. villosum & A. villosum & 35 & A. villosum & A. villosum \\
\hline 16 & A. villosum & A. villosum & 36 & A. villosum & A. villosum \\
\hline 17 & A. villosum var. xanthioides & A. villosum & 37 & A. villosum & A. villosum \\
\hline 18 & A. villosum var. xanthioides & A. villosum & 38 & A. villosum & A. villosum \\
\hline 19 & A. villosum var. xanthioides & A. villosum & 39 & A. villosum & A. villosum \\
\hline 20 & A. villosum var. xanthioides & A. villosum & 40 & A. villosum & A. villosum \\
\hline
\end{tabular}

\section{Discussion}

DNA barcoding has been developed as a rapid and reliable technique to identify species based on variations in the sequence of short standard DNA region(s) [19-24]. This tool is successfully used in a variety of biological applications, including discovering cryptic species, detecting invasive species, and reconstructing food webs [17]. Furthermore, it has been widely accepted as a technique to authenticate herbal medicinal materials (e.g., powder, processed roots, barks, and leaves) and in the detection of product substitution and contamination [25-28]. Unfortunately, it is very common for morphologically similar herbs to be used as adulterants in commercial herbal markets. Although the authentication of closely related species using DNA barcoding has been challenging, DNA barcoding can readily distinguish species that are morphologically similar but phylogenetically different [29].

In previous research on the identification of Amomi Fructus, DNA barcoding using the novel SNPs substantiated its effectiveness [1,9-11,15,16,30]. Based on these studies, we selected five DNA barcoding regions, that is, ITS, $r b c L, m a t K, r p o B$, and $t r n L-F$ intergenic spacer, to distinguish Amomi Fructus from its adulterants.

Among the original species of Amomi Fructus, the nuclear ribosomal DNA ITS region showed more SNPs than the plastid. The minimum sequence identity matrix of genuine Amomi Fructus samples showed that the ITS is more variable than the plastid regions. These results indicate that the ITS region has high levels of sequence differentiation among the species and shows greater discriminatory power than the plastid region.

Despite the high discriminatory efficiency of ITS, a single region may be insufficient to cover the various varieties [17], and it sometimes shows analytical problems in samples contaminated by fungi. Thus, multiple loci are necessary for the maximal identification and prevention of the fungal contamination problem. Firstly, we analyzed the CBOL-Plant Working Group recommendation of two-locus barcoding combination $r b c L+$ matK [21]. The $r b c L$ is one of the large subunits which encode the critical photosynthetic enzyme rubilose-1-5-bisphosphate carboxylase/oxygenase (RUBISCO), the first sequenced gene from plants [31]. The matk is also known as one of the most rapidly evolving genes and has been used as a marker to construct plant phylogenies [32-34]. This two-locus combination was expected as the universal barcode for land plants [21]. The $r b c L+$ mat $K$ combination shows a total of six SNPs among the original species of Amomi Fructus. The variation rate was lower than ITS and $m a t K$ alone was not suitable for the identification of Amomi Fructus. However, an $r b c L$ plus 
matK combination could successfully separate Amomi Fructus from the adulterants (data not shown). Even if this combination was a proper locus, the amplification size could be long for manufactured samples by various processing methods. Therefore, we tried to analyze additional locus rpoB and trnL-F intergenic spacer, which are shorter. At first, we analyzed the trnH-psbA locus, which is one of the most variable genome segments in the chloroplast of angiosperms [24], instead of rpoB. It was short and easily amplified in any species, but we had to eliminate this locus because of several non-specific indels. The $r p o B$ gene encodes the subunit of the chloroplast RNA polymerase and is currently considered as the core gene for DNA barcoding in bacteria [17] rather than plants. However, it has high universality and it yields high-quality sequences [17], a number of which have already been deposited in NCBI GenBank. Therefore, we chose the rpoB instead of $t r n H-p s b A$, even though it was not recommended by CBOL-Plant Working Group. trnL-F intergenic spacer has been used for molecular phylogenetic studies of various taxa since it was introduced by Taberlet et al. [35]. These two regions were also not quite successful as single-locus, but separated the samples followed by the species when combined together (data not shown). The results of the DNA barcoding of the plastid regions confirmed that the combination of the two regions is more efficient than the single region alone. Therefore, we combined all four plastid regions to perform the phylogenetic analysis using MrBayes (Figure 5). Concatenating the four plastid regions allowed the successful identification of each authentic species of Amomi Fructus and efficiently separated the adulterants.

Our results from DNA barcode analysis confirmed the ability of the classification for Amomi Fructus and the adulterants at the species level. Recently, Cui et al. reported the complete genome of A. villosum, A. villosum var. xanthioides and A. longiligulare via high-throughput sequencing [12]. They found five new divergent regions (atpH-atpI, trnD-trnY, accD-psaI, ycf4-cemA and trnI-ycf2), which were not useful as effective molecular markers. However, this was the first approach to sequence and determine the complete complete genome for Amomi Fructus. Thus, we used these deposited complete genome data as a reference in this work and further studies.

In addition, we attempted to provide the species-specific DNA marker to determine the origin of Amomi Fructus. DNA barcoding is a very powerful method to identify species; however, it is time-consuming and not cost-effective for monitoring distributed samples. Therefore, we tried to develop the DNA marker for Amomi Fructus. The SNP-based DNA Marker has been a successful method to identify the medicinal herbs from its adulterants [36-40]. In the case of Amomi Fructus, the recoded origin species in pharmacopoeia was different according to the country of origin. Two species, A. villosum var. xanthioides and A. villosum, were recorded in the Korean Pharmacopoeia [4]. A. longiligulare as well as the above two species are additionally registered in Chinese and Taiwan pharmacopoeias [5,6]. Therefore, the fruits of $A$. longiligulare should not be used as herbal medicine in Korea. In this study, we tried to develop one common DNA markers for A. villosum and A. villosum var. xanthioides and one marker for $A$. longiligulare. Unfortunately, we could not collect correctly identified A. villosum var. xanthioides samples and, therefore, we used the NCBI GenBank Database for Amomi Fructus instead, as previously reported [1,12]. To confirm any PCR reaction errors, we designed the internal standard marker based on 5.8S ribosomal DNA region in ITS. As shown in Figure 4, the designed DNA marker provided reliable differentiation results.

With the developed DNA markers, we monitored commercial Amomi Fructus samples in herbal markets in Korea and other Asian countries. To confirm the DNA marker result, we analyzed the ITS nucleotide sequences together. As shown in Figure 5, misuse existed in some samples. Some of them were distributed with incorrect medicinal names, such as 'A. longiligulare' to 'A. villosum', 'A. villosum' to 'A. villosum var. xanthioides' and 'A. longiligulare' to 'A. villosum var. xanthioides'. Furthermore, we found a previously unreported new adulterant of Amomi Fructus. Some of the A. longiligulare samples were identified as Amomum ghaticum through the blast analysis in NCBI GenBank data. A. ghaticum was originally published in Indian J. Forest. 11: 3221988 publ. 1989 [41]. A. ghaticum has not been reported as an adulterant and is known as an endemic plant in the Western Ghats of India [42,43]; therefore, further research will be necessary. In this study, we confirmed the ability of DNA barcoding 
analysis for the identification of Amomi Fructus and its adulterants and suggested proper regions for classified the Amomi Fructus. Moreover, we have presented a species-specific DNA marker for the identification of Amomi Fructus. This may be a useful tool to reduce the time and cost involved in monitoring and confirming the quality Amomi Fructus for commercial usage.

$$
\text { Tree scale: } 0.01 \longmapsto
$$

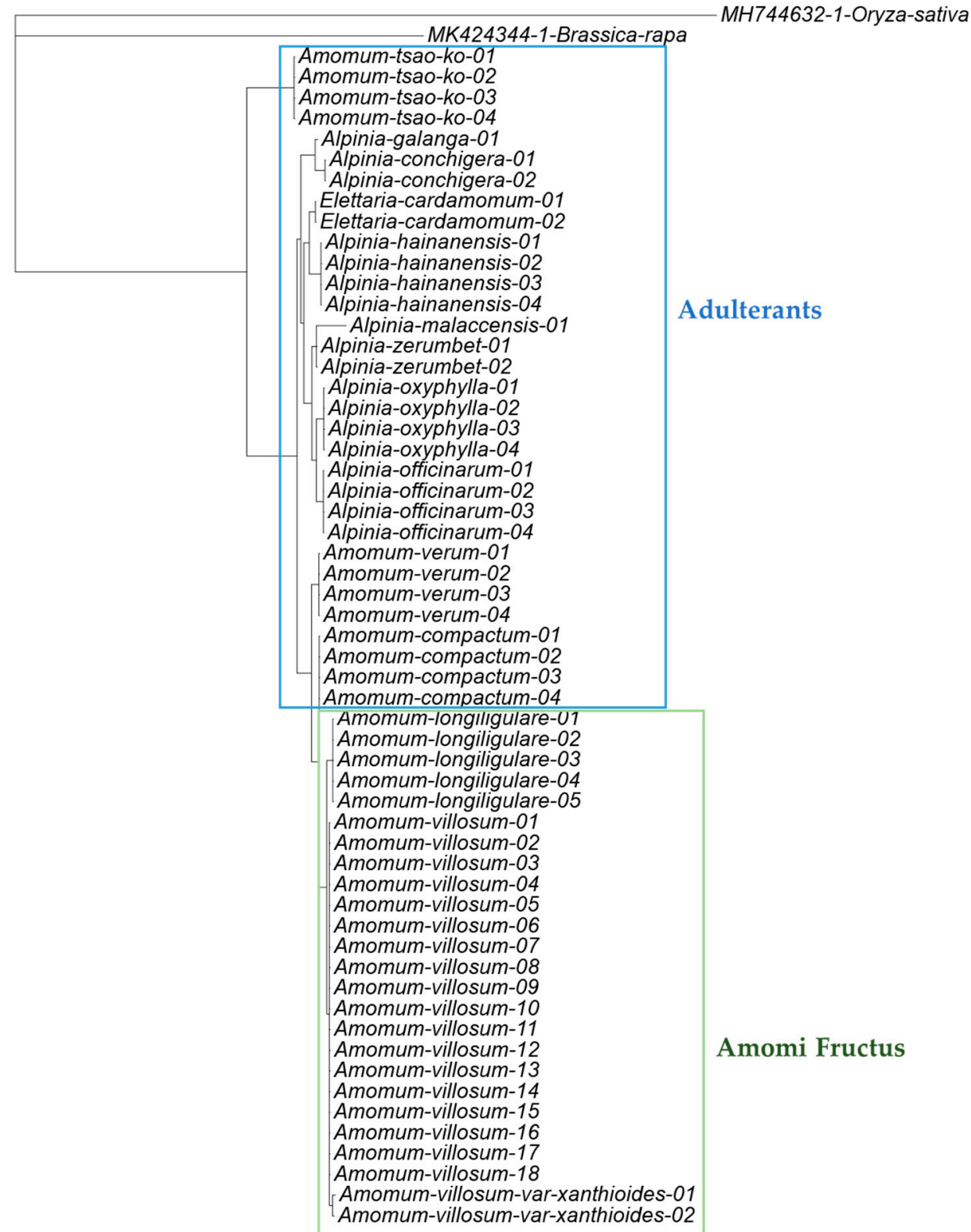

Figure 5. Phylogenetic analysis of Amomi Fructus and its adulterants based on the concatenate nucleotide sequences of four plastid regions (matK, $r b c L, r p o B$ and $t r n L-F$ intergenic spacer) using the MrBayes.

\section{Materials and Methods}

\subsection{Plant Materials}

For the identification of species of Amomi Fructus and its adulterants, fifty-five samples of crude drugs and voucher specimens of Amomi Fructus were collected or purchased from the habitats, cultivation areas, and local markets in Korea, China, and Myanmar (Table 1). Some samples 
were received from the Korean institute of Oriental Medicine. For monitoring Amomi Fructus samples in the Korean commercial markets, a total of forty crude drug samples were tested (Table 3). All the samples and isolated genomic DNA were deposited at the herbarium of Korean Medicine in Wonkwang University.

\subsection{Preparation of Genomic DNA}

The genomic DNA was extracted from the Amomi Fructus according to the manual of NucleoSpin ${ }^{\circledR}$ Plant II kit (Macherey-Nagel, Dueren, Germany) with PL1 lysis buffer. For some samples, 10\% cetyltrimethyl ammonium bromide $(\mathrm{CTAB})$ and $0.7 \mathrm{M} \mathrm{NaCl}$ were used to remove the phenolic compounds and polysaccharides.

\subsection{PCR Amplification for DNA Barcode Analysis}

For ITS amplification, PCR was performed using T-personal cycler (Biometra, Germany). In brief, $600 \mathrm{nM}$ of primer set of ITS1 (5"'-TCCGTAGGTGAACCTGCGG-3') and ITS4 (5'-TCCTCCGCTT ATTGATATGC-3') [44], 1X AccuPower ${ }^{\circledR}$ GoldHotStart Taq PCR PreMix (Bioneer, Daejeon, Korea), and a $30 \mathrm{ng}$ of genomic DNA were used for PCR amplification. PCR cycling conditions followed by a pre-denaturation process $\left(95^{\circ} \mathrm{C}, 5 \mathrm{~min}\right)$ were as follows: Denaturation process $\left(95{ }^{\circ} \mathrm{C}, 30 \mathrm{~s}\right)$; annealing process $\left(52{ }^{\circ} \mathrm{C}, 30 \mathrm{~s}\right)$; extension process $\left(72{ }^{\circ} \mathrm{C}, 40 \mathrm{~s}\right) \times 36$ cycles; final extension process (72 $\left.{ }^{\circ} \mathrm{C}, 5 \mathrm{~min}\right)$. For chloroplast DNA barcoding regions, rbcL a-f ( $5^{\prime}$-ATGTCACCACAAACAGAGAC TAAAGC-3')/724R (5'-TCGCATG TACCTGCAGTAGC-3') and 390F (5'-CGATCTATTCATTCAAT ATTTC-3')/1326R (5'-TCTAGCACAC GAAAAGTCGAAGT-3') primer sets were used for amplification of $r b c L$ and $m a t K$ regions $[24,45,46]$. rpoB1 (5'-AAGTGCATTGTTGGAACTGG-3')/rpoB3 (5'-CCGTAT GTGAAAAGAAGTATA-3 $\left.{ }^{\prime}\right)$ and trnL-e (5'-GGTTCAAGTCCCTCTTATCCC- $\left.3^{\prime}\right) / \operatorname{trnL}-\mathrm{f}\left(5^{\prime}\right.$-ATTTGA ACTGGTGACACGAG-3') primer sets were used for $r p o B$ and $t r n L-F$ intergenic spacer regions [23,35]. The amplified PCR product was separated from other gradients using 1.5\% agarose gel electrophoresis after staining by the addition of Safe-whiteTM (abm, Richmond, Canada). Amplified products were analyzed using MyImage (Seoulin Biotechnology, Seongnam, Korea).

\subsection{Determination of DNA Sequences of PCR Product}

PCR products separated from agarose gel were cloned using TOPcloner ${ }^{\mathrm{TM}}$ TA Kit (Enzynomics, Daejeon, Korea) and the DNA sequences of cloned PCR product were determined through the interpretation performed by Bioneer (Daejeon, Korea). For accuracy, the DNA barcode analysis process was performed independently three times from the preparation of the genome DNA stage.

\subsection{Analysis of DNA Sequences and Preparation of Dendrogram}

DNA sequences were analyzed using ClustalW multiple sequence alignment (Bioedit, v7.0.9; available from http://www.mbio.ncsu.edu/BioEdit/page2.html) and confirmed with multiple sequence alignment in MAFFT (MAFFT, v7; available from https://mafft.cbrc.jp/alignment/server/). To verify the polymorphisms, represented by IUPAC symbols in the sequence data, all sequences were generated at least twice. The chromatograms of nucleotide sequences, which were provided from Bioneer sequencing service, were compared. Evolutionary analyses were conducted in MEGA X (v10.0.5; available from https://www.megasoftware.net/). Phylogenic trees were constructed for each region using distance-based method (UPGMA and NJ) and the evolutionary distances in tree were computed using the Maximum Composite Likelihood method. Phylogenetic analysis of concatenate four plastid regions was constructed using MrBayes (MrBayes, 3.2.6_1; available from https://ngphylogeny.fr/ tools/tool/281/form). All the analyzed sequences were compared with NCBI GenBank using BLAST (Altschul et al. 1990) [47]. Newly determined nucleotide sequences were deposited in NCBI GenBank. As the outgroups, we used Brassica rapa (MK424344.1) and Oryza sativa (MH744632.1) deposited in the NCBI GenBank [48]. 


\subsection{Multiplex PCR}

For the multiplex PCR amplification with developed DNA markers, each $0.5 \mathrm{pmol}$ of the primers AVF1 (5'-TGGATGATTGTGAACGTGTCAACA-3') and ALF1 (5'-AGGGTCTCTTTGAGGACACAT CCC G-3'), each 0.5 pmol of the primers ISR (5'-AAAGACTCAATGGTTCACGAG-3') and ISF (5'-GACTCTCGGCAATGGATATCT-3'); 1 X AccuPower ${ }^{\circledR}$ GoldHotStart Taq PCR PreMix (Bioneer, Daejeon, Korea), and a $20 \mathrm{ng}$ of genomic DNA were used for PCR amplification. During the 23-cycle PCR process, pre-denaturation was conducted for $5 \mathrm{~min}$ at $95^{\circ} \mathrm{C}$ and denaturation for $30 \mathrm{~s}$ at $95^{\circ} \mathrm{C}$. The annealing process was conducted for $10 \mathrm{~s}$ at $58.5^{\circ} \mathrm{C}$ and the extension process for $20 \mathrm{~s}$ at $72{ }^{\circ} \mathrm{C}$. A final reaction step was conducted for $5 \mathrm{~min}$ at $72{ }^{\circ} \mathrm{C}$. The amplified products were separated on $2 \%$ agarose gel and revealed by staining with Safe-whiteTM (abm, Richmond, Canada). The specific amplified regions by developed DNA marker were confirmed by analysis of nucleotide sequences.

\section{Conclusions}

The purpose of this study was to provide efficient and proper methods to identify and monitor the origin of Amomi Fructus, which has an increased usage not only in commonly used foods and drugs but also cosmetic ingredients. Moreover, adulterant problems frequently occurred due to morphological similarity. We suggested proper DNA barcode regions to distinguish the Amomi Fructus from the adulterants. Furthermore, we designed an SNP-based DNA marker for Amomi Fructus. The monitoring results using multiplex PCR with AVF1/ISR/ISF/ALF1 DNA markers successfully identify the species in Amomi Fructus. We hope that our approach will prove a useful tool to reduce the time and cost of monitoring and confirming the quality of Amomi Fructus for commercial usage.

Supplementary Materials: The following are available online. Table S1. The sequence identity matrix among the Amomi Fructus and its several adulterants based on the ITS nucleotide sequence. Table S2. The sequence identity matrix among the Amomi Fructus and its several adulterants based on the four DNA barcode loci in chloroplast genome. Figure S1. Neighbor-joining (NJ) tree of Amomi Fructus and its adulterants based on the nucleotide sequences of (A) matK, (B) $r b c L,(C) r p o B$ and (D) $t r n L-F$ intergenic sapcer regions of sample listed in Table 1. As outgroups, Brassica rapa and Oryza sativa were used.

Author Contributions: Conceptualization, E.J.D., G.L. and J.-H.K.; methodology, G.L. and E.J.D.; validation, E.J.D., G.L. and J.-H.K.; formal analysis, G.L.; investigation, E.J.D.; resources, G.L. and J.-H.K.; data curation, E.J.D., G.L.; writing-original draft preparation, E.J.D.; writing—review and editing, G.L. and J.-H.K.; visualization, E.J.D., G.L.; supervision, E.J.D. and G.L.; project administration, G.L.

Funding: This paper was supported by Wonkwang University in 2019.

Conflicts of Interest: The authors declare no conflict of interest.

\section{References}

1. Huang, Q.; Duan, Z.; Yang, J.; Ma, X.; Zhan, R. SNP Typing for Germplasm identification of Amomum villosum Lour. based on DNA barcoding markers. PLoS ONE 2014, 9, e114940. [CrossRef]

2. Ju, Y.S.; Choi, G. Discrimination on Korean Medicinal Herbs for Clinicians; Korea Institute of Oriental Medicine: Daejeon, Korea, 2016; Volume 1, pp. 76-78.

3. Korea Institute of Oriental Medicine. Defining dictionary for medicinal herbs [Korean, 'Hanyak Giwon Sajeon']. 2019. Published on the Internet. Available online: http://boncho.kiom.re.kr/codex/ (accessed on 10 October 2019).

4. Ministry of Food and Drug Safety. The Korean Pharmacopoeia, 11th ed.; Ministry of Food and Drug Safety: Osong, Korea, 2017; Volume 2, the article of pharmaceutical drug; p. 50.

5. Commission, C.P. Pharmacopoeia of the Peoples Republic of China; China Medical Science Press: Beijing, China, 2015. Available online: https://www.tsoshop.co.uk/Medical/Pharmacopoeia/Chinese-Pharmacopoeia/ (accessed on 18 August 2019).

6. Ministry of Health and Welfare Taiwan. Taiwan Herbal Pharmacopeia, 2nd ed.; Ministry of Health and Welfare Taiwan: Taiwan, China, 2013; pp. 164-166.

7. Tang, L.; He, G.; Su, J.; Xu, H. The strategy to promote the development of industry of genuine medicinal material of Amomum villosum. Chin. Agric. Sci. Bull. 2012, 28, 94-99. 
8. Quan, Q.; Lin, J.C.; Liang, J.M.; Hu, Z.L.; Huang, J.X. Compare on the content of ronyl Acetate and total volatile oil in Fructus Amomi from different producing area. Guid. J. Tradit. Chin. Med. Pharm. 2017, 23, 70-73.

9. Chen, J.; Ding, P.; Xu, X.; Xu, H. A resource investigation and commodity identification of Fructus Amomi. J. Chin. Med. Mater. 2001, 24, 18.

10. Han, J.P.; Li, M.N.; Shi, L.C. Identification of Amomi fructus and its adulterants based on ITS2 sequences. Glob. Tradit. Chin. Med. 2011, 4, 99-102.

11. Choi, G. List of Fake Korean Medicinal Herbs; Korea Institute of Oriental Medicine: Daejeon, Korea, 2016; pp. 43-44.

12. Cui, Y.; Chen, X.; Nie, L.; Sun, W.; Hu, H.; Lin, Y.; Li, H.; Zheng, X.; Song, J.; Yao, H. Comparison and phylogenetic analysis of chloroplast genomes of three medicinal and edible Amomum Species. Int. J. Mol. Sci. 2019, 20, 4040. [CrossRef]

13. Huang, Q.I.; Yang, J.F.; Yan, P.; Zhan, R.T.; Xu, H.; Chen, W.W. Establishment and optimization of ISSR-PCR reaction system for Amomum villosum Lour. Lishizhen Med. Mater. Med. Res. 2010, 10, 2478-2480.

14. Wang, P.; Huang, F.; Zhou, L.; Cao, L.; Liang, S.; Xu, H.; Liu, J. Analysis of Amomun villosum species and some adulterants of Zingiberaceae by RAPD. J. Chin. Med. Mater. 2000, 23, 71-74.

15. Huaxin, P.; Feng, H.; Peixun, W.; Lian, Z.; Liuying, C.; Ruiyan, L. Identification of Amomum villosum, Amomum villosum var. xanthioides and Amomum longiligulare on ITS-1 sequence. Zhong Yao Cai 2001, 24, 481-483.

16. Zhou, L.; Wang, P.; Huang, F.; Cao, L.; Liang, R. ITS sequence analysis of Amomum villosum. Chin. Tradit. Herb. Drugs. 2002, 33, 72-75.

17. Vijayan, K.; Tsou, C. DNA barcoding in plants: Taxonomy in a new perspective. Curr. Sci. 2010, 99, 1530-1541.

18. eFloras. Missouri Botanical Garden St. Louis, MO Harvard University Herbaria: Cambridge, MA, USA, 2008; Volume 24, pp. 333-346. Available online: http://www.efloras.org (accessed on 15 October 2019).

19. Herbert, P.D.N.; Cywinska, A.; Ball, S.L.; de Waard, J.R. Biological identifications through DNA barcodes. Proc. R. Soc. Lond. Ser. B. 2003, 270, 313-321. [CrossRef] [PubMed]

20. Herbert, P.D.N.; Gregory, T.R. The promise of DNA barcoding for taxonomy. Syst. Biol. 2005, 54, 852-859. [CrossRef] [PubMed]

21. Hollingsworth, P.M.; Forrest, L.L.; Spouge, J.L.; Hajibabaei, M.; Ratnasingham, S. A DNA barcode for land plants. Proc. Natl. Acad. Sci. USA 2009, 106, 12794-12797. [CrossRef] [PubMed]

22. Hollingsworth, P.M.; Graham, S.W.; Little, D.P. Choosing and using a plant DNA barcode. PLoS ONE 2011, 6, e19254. [CrossRef] [PubMed]

23. Ford, C.S.; Ayres, K.L.; Toomey, N.; Haider, N.; Stahl, J.A.; Kelly, L.J.; Wikström, N.; Hollingsworth, P.M.; Duff, R.J.; Hoot, S.B.; et al. Selection of candidate coding DNA barcoding regions for use on land plants. Bot. Linn. Soc. 2009, 159, 1-11. [CrossRef]

24. Kress, W.J.; Erickson, D.L. A two-locus global DNA barcode for land plants: The coding rbcL gene complements the noncoding trnH-psbA spacer region. PLoS ONE 2007, 2, e508. [CrossRef]

25. Vinitha, M.R.; Kumar, U.S.; Aishwarya, K.; Sabu, M.; Thomas, G. Prospects for discriminating Zingiberaceae species in India using DNA barcodes. J. Integr Plant. Biol. 2014, 56, 760-773. [CrossRef]

26. Wang, H.; Kim, M.K.; Kwon, W.S.; Jin, H.; Liang, Z. Molecular authentication of Panax ginseng and ginseng products using robust SNP markers in ribosomal external transcribed spacer region. J. Pharm. Biomed. Anal. 2011, 55, 972-976. [CrossRef]

27. Wang, H.; Kim, M.K.; Kim, Y.J.; Lee, H.N.; Jin, H. Molecular authentication of the oriental medicines Pericarpium Citri Reticulatae and Citri Unshius Pericarpium using SNP markers. Gene 2012, 494, 92-95. [CrossRef]

28. Kim, J.H.; Doh, E.J.; Lee, G.S. Evaluation of Medicinal Categorization of Atractylodes japonica Koidz. By using internal transcribed spacer sequencing analysis and HPLC fingerprinting combined with statistical tools. Evid. Based Complement. Alternat. Med. 2016. [CrossRef]

29. Mishra, P.; Kumar, A.; Nagireddy, A.; Mani, D.N.; Shukla, A.K.; Tiwari, R. DNA barcoding: An efficient tool to overcome authentication challenges in the herbal market. Plant. Biotechnol. J. 2016, 14, 8-21. [CrossRef] [PubMed]

30. Duan, L.S.; Zhang, L.X.; Peng, J.M.; Jie, M.A. Original report on investigation of Ammomum villosum germplasm resources in Xishuangbanna. Lishizhen Med. Mater. Med. Res. 2009, 20, 627-628. 
31. Zurawski, G.; Perrot, B.; Bottomley, W.; Whitefield, P.R. The structure of the gene for the large subunit of ribulose-1-5-bisphosphate carboxylase from spinach chloroplast DNA. Nucleic Acids Res. 1981, 9, 3251-3270. [CrossRef] [PubMed]

32. Wolfe, K.H. Protein-coding genes in chloroplast DNA: Compilation of nucleotide sequence, data base entries and rates of molecular evolution. In Cell Culture and Somatic Cell Genetics of Plant; Vasil, K., Ed.; Academic Press: San Diego, CA, USA, 1991; Volume 7BI, pp. 467-482.

33. Hilu, K.W.; Liang, H. The matk gene: Sequence variation and application in plant systematics. Am. J. Bot. 1997, 84, 830-839. [CrossRef]

34. Kelchner, S.A. The evolution of noncoding chloroplast DNA and its application in plant systematics. Ann. Mo. Bot. Gard. 2000, 87, 482-498. [CrossRef]

35. Taberlet, P.; Gielly, L.; Pautou, G.; Bouvet, J. Universal primers for amplification of three non-coding regions of the chloroplast DNA. Plant. Mol. Biol. 1991, 17, 1105-1109. [CrossRef]

36. Doh, E.J.; Paek, S.H.; Lee, G.S.; Lee, M.Y.; Oh, S.E. Application of partial internal transcribed spacer sequences for the discrimination of Artemisia capillaris from other Artemisia species. Evid. Based Complement. Alternat. Med. 2016. [CrossRef]

37. Lee, O.R.; Kim, M.K.; Yang, D.C. Authentication of medicinal plants by SNP-based multiplex PCR. Methods Mol. Biol. 2012, 862, 135-147.

38. Kim, W.J.; Moon, B.C.; Yang, S.; Han, K.S.; Choi, G.; Lee, A.Y. Rapid authentication of the herbal medicine plant species Aralia continentalis Kitag. and Angelica biserrata C.Q. Yuan and R.H. Shan using ITS2 sequences and Multiplex-SCAR markers. Molecules 2016, 21, 270. [CrossRef] [PubMed]

39. Kim, Y.; Kim, A.-Y.; Jo, A.; Choi, H.; Cho, S.-S.; Choi, C. Development of user-friendly method to distinguish subspecies of the Korean medicinal herb Perilla frutescens using multiplex-PCR. Molecules 2017, 22, 665. [CrossRef] [PubMed]

40. Dechbumroong, P.; Aumnouypol, S.; Denduangboripant, J.; Sukrong, S. DNA barcoding of Aristoloc10hia plants and development of species-specific multiplex PCR to aid HPTLC in ascertainment of Aristolochia herbal materials. PLoS ONE 2018, 13, e0202625. [CrossRef] [PubMed]

41. The Plant List, 1.1 ed. Available online: http://www.theplantlist.org/ (accessed on 1 January 2013).

42. Thomas, V.P.; Sabu, M. Two species of Amomum (Zingiberaceae) from Western Ghats, India. Edinb. J. Bot. 2012, 69, 313-321. [CrossRef]

43. Shetty, B.V.; Kaveriappa, K.M. An arboretum of endemic plants of Western Ghats at Mangalore University campus, Karnataka, India. Zoos' Print J. 2001, 16, 431-438. [CrossRef]

44. White, T.J.; Bruns, T.; Lee, S.; Taylor, J.W. Amplification and direct sequencing of fungal ribosomal RNA genes for phylogenetics. In PCR Protocols: A Guide to Methods and Applications; Innis, M.A., Gelfand, D.H., Sninsky, J.J., White, T.J., Eds.; Academic Press: New York, NY, USA, 1990; pp. 315-322.

45. Fay, M.F.; Swensen, S.M.; Chase, M.W. Taxonomic affinities of Medusagyne oppositifolia (Medusagynaceae). Kew Bull. 1997, 52, 111-120. [CrossRef]

46. Cuénoud, P.; Savolainen, V.; Chatrou, L.W.; Powell, M.; Grayer, R.J.; Chase, M.W. Molecular phylogenetics of caryophyllales based on nuclear $18 \mathrm{~S}$ rDNA and plastid $r b c L$, atpB, and matK DNA sequences. Am. J. Bot. 2002, 89, 132-144. [CrossRef]

47. Altschul, S.F.; Gish, W.; Miller, W.; Myers, E.W.; Lipman, D.J. Basic local alignment search tool. J. Mol. Biol. 1990, 215, 403-410. [CrossRef]

48. National Center for Biotechnology Information (NCBI) [Internet]. Bethesda (MD): National Library of Medicine (US), National Center for Biotechnology Information; [1988]-[cited 2017 Apr 06]. Available online: https://www.ncbi.nlm.nih.gov/ (accessed on 19 November 2019).

Sample Availability: The nucleotide sequence data, besides those deposited in the NCBI GenBank, that support the findings of this study are available from the first or corresponding author upon request.

(C) 2019 by the authors. Licensee MDPI, Basel, Switzerland. This article is an open access article distributed under the terms and conditions of the Creative Commons Attribution (CC BY) license (http://creativecommons.org/licenses/by/4.0/). 